\title{
AN INTEGER LINEAR PROGRAMMING APPROACH APPLIED TO THE CERRADO (SAVANNA) MANAGEMENT
}

\author{
Henrique Moreira Dabien Haddad ${ }^{1}$; Lucas Rezende Gomide ${ }^{2}$; Bruno Rogério Cruz ${ }^{1}$; \\ Sérgio Teixeira da Silva ${ }^{3}$ \\ ${ }^{1}$ Forest Eng., Attending Master Degree in Forest Engineering, UFLA, MG, Brasil - hmoreiralavras@yahoo.com.br; \\ brunor.cruz@hotmail.com.br \\ ${ }^{2}$ Forest Eng., Dr., Department of Forest Engineering, UFLA, Lavras, MG, Brasil - lucasgomide@ dcf.ufla.br \\ ${ }^{3}$ Forest Eng., PhD., Student in Forest Engineering, UFLA, Lavras, MG, Brasil - setesi@uol.com.br
}

Received for publication: 08/03/2013 - Accepted for publication: 18/11/2013

\begin{abstract}
Cerrado presents great potential for the use of its resources, whether timber or non-timber, as fruits, firewood and charcoal. Thus, this study aimed to test the use of forest regulation model type I in a remnant of cerrado, applying the integer linear programming. The studied area was a remnant of cerrado sensu stricto located in São Romão - MG. The type of forest management carried out was the strip cutting. with post regeneration conduction. The model type I was applied generating 8 scenarios considering 14 years of planning horizon. The tested scenarios considered the area control, volume control and also both controls in the same model, where the objective function was to maximize the present value of revenues (PVR). After data processing it was observed that scenario 5 was the best, because it obtained the lowest amplitude variation $(425-575 \mathrm{ha} / \mathrm{year})$ and volume $\left(18.000-21.000 \mathrm{~m}^{3} /\right.$ year $)$ of the exploited surface limits, presenting a PVR of $\mathrm{R} \$ 4,004,561.58$. It is possible to conclude that the developed models were able to regulate the volumetric yield in constant flows over the planning horizon, representing a promising alternative for the sustainable planning of the wood resources of the cerrado.

Keywords: Mathematical programming; forest regulation; forest management.
\end{abstract}

\section{Resumo}

Uma abordagem aplicada da programação linear inteira no manejo do cerrado. O cerrado apresenta um grande potencial de uso de seus recursos, sejam eles madeireiros ou não madeireiros, como frutos, lenha e carvão vegetal. Assim, o trabalho teve como objetivo testar o uso do modelo tipo I de regulação florestal em um remanescente de cerrado utilizando a programação linear inteira. A área de estudo foi um remanescente de cerrado sensu stricto localizado em São Romão - MG. O regime de manejo elaborado foi o corte em faixas com posterior condução da regeneração. O modelo tipo I foi aplicado gerando 8 cenários em um horizonte de planejamento de 14 anos. Os cenários testados consideraram o controle por área, por volume, bem como ambos no mesmo modelo, sendo a função objetivo o valor presente das receitas (VPR) a ser maximizado. Após o processamento dos modelos observou-se que o cenário 5 foi o melhor, possuindo limites de área explorada $(425$ - 575 ha/ano) e volumétricos $(18.000$ $21.000 \mathrm{~m}^{3} / \mathrm{ano}$ ) com menor variação de amplitude, apresentando R\$4.004.561,58 de VPR. Pôde-se concluir que os modelos formulados foram capazes de regular a produção volumétrica em fluxos constantes ao longo do horizonte de planejamento, em sua grande maioria, constituindo-se de uma alternativa promissora ao planejamento sustentável dos recursos madeireiros do cerrado.

Palavras-chave: Programação matemática; regulação florestal; manejo florestal.

\section{INTRODUCTION}

Cerrado is one of the most important physiognomies occurring in Brazil, and this is proved by the constant development of scientific researches in the last decades. However, when the management of its resources is observed, there is lack of information, mainly at a strategic level. Although this is a reality, it is not possible to forget that forest management is made of principles and techniques that help in the sustainable use of the available resources. 
According to Scolforo et al. (2008), cerrado vegetation in the state of Minas Gerais presents potential for wood production in privileged regions of the north/northeast, where vegetation has biggger biomass. Due to structural characteristics of the native plants, wood production of cerrado is practically turned to production on charcoal, to meet steel industry requirements.

One positive silvicultural characteristic of the cerrado vegetation is the capability to grow shoots after interventions (BARREIRA et al., 2000; MORAIS et al., 2011), saving the need to make enrichment plantings or apply other silvicultural techniques that are commonly observed in the uneven aged forests, thus making the cerrado management economically viable (OLIVEIRA et al., 2002). However this viability depends on the level of intervention (SCOLFORO et al., 2008), cutting cycles (SILVA et al., 2011), productivity (LEITE, 1998), cost of the land (OLIVEIRA et al., 2000) and market variables (COELHO JUNIOR et al., 2008). Furthermore, the alteration of flowering composition of the cerrado is little affected, considering the capability to grow shoots and the care during/after the exploitation activity.

Production sustainability is a challenge to planning and organization of the forestry activity, being a component of the forest regulation. Leuschner (1984) defines the concept of regulated forest as being the one where annual or periodical production with equal volume, dimensions or quality, takes place. Davis and Johnson (1987) completed this concept stating that some requirements are essential to obtain a completely regulated forest, and they have relation with growth rate, age equilibrium of the areas, approximately equal or periodic production of trees with desired dimension and quality which are regularly available for logging. In resume, it is conceptually expected to obtain an ideal forest, although it is rarely achieved, and for this reason the term normal forest is used (LEUSCHNER, 1984).

Silva and Ribeiro (2006) describe that forest rotation is one of the most important factors in forest planning and regulation, since rotation includes the time period from planting to cutting, and impacts on the productive structure.

A recurring factor in works on forest regulation is the maximization of profit for the forest as a whole, in opposition to the vision of the optimization at the forest compartment level. Forest regulation therefore grants the annual wood production, consolidating itself as an important method for the industry in the search for production sustainability (SILVA et al., 2007), and supporting the planning of activities in the three hierarchic levels (strategic, tactic and operational). According to Chiavenato (2006), planning consists in a set of decision makings which affect the project over the planning horizon, with the aim to absorb the uncertainty of future and allow the companies more consistent performances.

A form to support the decision making process is the use of mathematical programming techniques, as for example the linear programming. According to Montevecchi (2000), this method aims to maximize/minimize an objective function, formed by profits and costs, with the intention to efficiently allocate limited resources.

Therefore, the aim of this work was to apply the integer linear programming to the production regulation of a cerrado sensu stricto remnant, considering an exploitation structure organized in strips, as permitted by legislation in the state of Minas Gerais. Furthermore, to verify the viability of the model I regulation in this type of physiognomy, considering a planning horizon of 14 years.

\section{MATERIAL AND METHODS}

\section{Characterization of the studied area}

The forestry project is located in the municipality of São Romão - MG, with a total area of approximately 7,706 hectares, being the native vegetation classified as cerrado sensu stricto. The municipality lays at an average altitude of $\mathbf{4 2 5 . 5}$ meters and the climate is Aw type, typical tropical wet and dry (savanna), according to the Köppen classification. Mean temperature in the coldest month is above $18{ }^{\circ} \mathrm{C}$ (NIMER, 1979) and the type of predominant soil is neosol (SCOLFORO et al., 2008).

\section{Volumetric quantification of the woodstock}

Forest inventory to determine the volume of wood was organized defining 157 rectangular sample stands, each with an area of $1000 \mathrm{~m}^{2}$, sistematically distributed and 700 meters far each other. Sample stands were geographically identified with UTM coordinates and then circumference at breast height $(\mathrm{CBH})$, at 1.30 meters from the ground, and the total height of all the plants were measured. Inclusion criteria for plants was $\mathrm{CBH} \geq 15,7 \mathrm{~cm}$. Plants volume was obtained according to the equation proposed by Rufini et al. (2010).

After obtaining the volume per each sample, spacial interpolation of the volume variable was 
performed using the kriging method, according to what described by Alvarenga (2012). Volumetric production was then divided into 5 classes of productivity including the entire area of the forestry project (Figure 1).

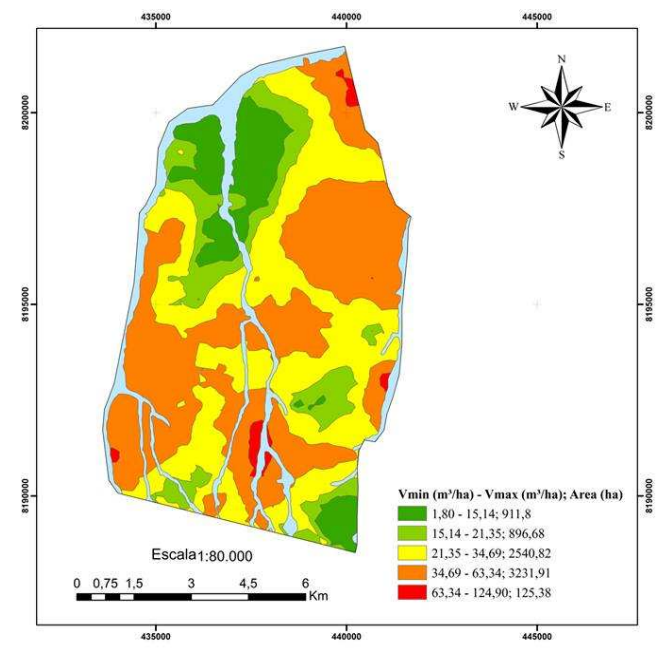

Figure 1. Woodstock predicted $\left(\mathrm{m}^{3} / \mathrm{ha}\right)$ for the cerrado sensu stricto in the project area.

Figura 1. Estoque de madeira estimado $\left(\mathrm{m}^{3} / \mathrm{ha}\right)$ para o cerrado sensu stricto na área do projeto.

Source: Alvarenga (2012).

\section{Division into stands and definition of the exploitation strips}

After the volumetric productivity map was obtained, the areas where exploitation was forbidden were identified and excluded, thus defining the effective area where the forest management plan was to be applied.

Division of the area into stands was then carried on, limiting the maximum area of each stand at 100 ha and also defining the roads between them. This way, 83 stands were created with a potential effective area to be exploited of 6,849 ha. After definition of stands, a further step was to define the exploitation strips, considering a maximum width of $100 \mathrm{~m}$ (Figure 2). Calculation of the volume per strip was performed multiplying the area of each polygon located in the strip by the central value of the productivity class, to which the respective polygon belonged. Thus, the sum of these partial volumes gave the total volume of the strip.

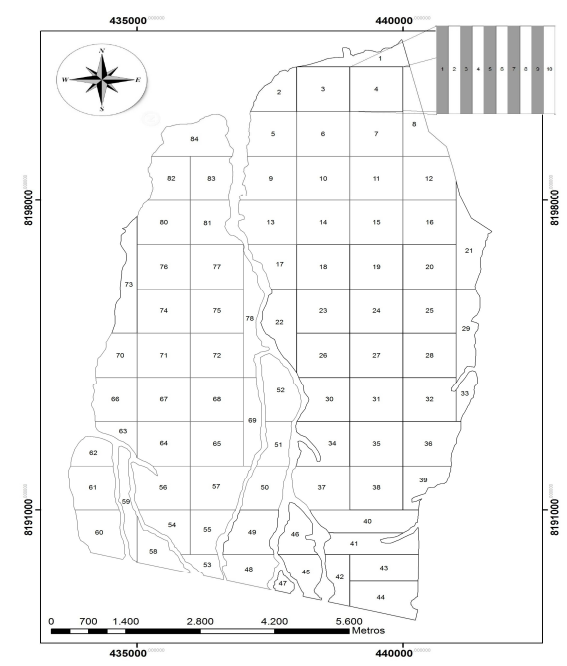

Figure 2. Final map of the effective management area to be imaged and regulated over the planning horizon of 14 years.

Figura 2. Mapa final da área efetiva de manejo a ser trabalhada e regulada ao longo do horizonte de planejamento de 14 anos. 


\section{Mathematical formulation for the forest regulation}

The executive order $\mathrm{n}^{\circ} 191$, of the IEF/MG, determines that the management plan to be applied in the studied area belongs to the category defined as Simplified Forest Management Planning in Strips. This planning is intended as the exploitation to be performed in strips, through clear cut, without taking roots off, with a maximum intervention limit of 50\% in the compartment area. This means that the remaining strips must be alternated to the exploited ones, and must always be equal or bigger than the latter, to ensure regeneration until the next logging cycle.

Starting from these legal recommendations, the management prescriptions for the compartments were defined, considering management in strips as the chosen option Thus, compartments had a total of 14 management alternatives (exploitation options), with the options from 1 to 7 being related to cutting of the even strips in the first seven years of the planning horizon, and the odd strips in the second step. The opposite of this procedure is related to options from 8 to 14 (Table 1). In the end, only one management planning should be chosen for each compartment.

Due to the lack of studies in this area about growing and production rates, a mean annual increment (MAI) of $2.07 \mathrm{~m}^{3}$.(ha.year) ${ }^{-1}$ was adopted, as being the mean between some studied values. According to Leite (1998), the MEI in an area of cerrado strictu senso with a lower population density reaches $1.52 \mathrm{~m}^{3}$.(ha.year) $)^{-1}$, and $2.61 \mathrm{~m}^{3}$.(ha.year) ${ }^{-1}$ in areas with higher population density, in the municipality of João Pinheiro, northeastern region of Minas Gerais.

Volumetric production of wood was dimensioned for the supply of an hypothetical market, where the price paid was determined as $\mathrm{R} \$ 25,00 \mathrm{~m}^{-3}$. The annual interest rate of $8 \%$ was used in the decapitalization of the net revenue, thus obtaining the present value of revenue (PVR).

Table 1. Illustrative example of generation of the management prescriptions options considering exploitation of strips over the planning horizon.

Tabela 1. Exemplo ilustrativo de geração das prescrições de manejo considerando opções de exploração das faixas ao longo do horizonte de planejamento.

\begin{tabular}{|c|c|c|c|c|c|c|c|c|c|c|c|c|c|c|c|}
\hline \multirow{2}{*}{$\begin{array}{l}\text { Compar } \\
\text { tment }\end{array}$} & \multirow{2}{*}{ M.A. } & \multicolumn{14}{|c|}{ Planning horizon (years) } \\
\hline & & $\mathbf{1}$ & 2 & 3 & 4 & 5 & 6 & 7 & 8 & 9 & 10 & 11 & 12 & 13 & 14 \\
\hline \multirow[t]{14}{*}{1} & 1 & $\mathrm{P}$ & & & & & & & I & & & & & & \\
\hline & 2 & & $P$ & & & & & & & I & & & & & \\
\hline & 3 & & & $\mathrm{P}$ & & & & & & & I & & & & \\
\hline & 4 & & & & $P$ & & & & & & & I & & & \\
\hline & 5 & & & & & $P$ & & & & & & & I & & \\
\hline & 6 & & & & & & $P$ & & & & & & & I & \\
\hline & 7 & & & & & & & $\mathrm{P}$ & & & & & & & I \\
\hline & 8 & I & & & & & & & $P$ & & & & & & \\
\hline & 9 & & I & & & & & & & $P$ & & & & & \\
\hline & 10 & & & I & & & & & & & $P$ & & & & \\
\hline & 11 & & & & I & & & & & & & $\mathrm{P}$ & & & \\
\hline & 12 & & & & & I & & & & & & & $\mathrm{P}$ & & \\
\hline & 13 & & & & & & I & & & & & & & $P$ & \\
\hline & 14 & & & & & & & I & & & & & & & $P$ \\
\hline
\end{tabular}

$\overline{\text { (MA: management alternative, }} \overline{\mathrm{P}} \overline{\mathrm{i}}$ even strip exploitation, I: odd strip exploitation).

The mathematical model used in this study correspond to the I model, according to the definition by Johnson and Sheurmann (1977), composed by the following structure: (1) objective function dimensioned to maximize the present value of revenues (PVR) of the area; (2) integrity constraint of the management units; (3) and (4) volumetric production flux control constraints; (5) and (6) control constraints of the exploitable area; (7) constant flux (even flow) constraint in area (ha); (8) constant flux (even flow) in volume $\left(\mathrm{m}^{3}\right)$; and (9) binary constraints on decision variables of the model. All constraints were used according to each established scenery, where: $M$ - is total number of compartments to be managed in the cerrado area; $P$ - is total number of management alternatives for each compartment to be managed; ${ }^{x_{i j}}-$ is a decision binary variable $\{0,1\}$ of the model referred to management alternative $j$ to be applied in 
compartment $i$ located in the area; ${ }^{r_{i j}}$ - is the PVR of the compartment $i$ given by management alternative $j$; $a_{i j k}$ - total area (ha) to be exploited in the time period $k$ of the planning horizon referred to compartment $i$ and management alternative $j ; v_{i j k}$ - total volume $\left(\mathrm{m}^{3}\right)$ to be exploited in the time period $k$ of the planning horizon referred to compartment $i$ and management alternative $j ; H P$ - planning horizon of the project; $k$ period of time belonging to the planning horizon $(H P) ;{ }^{V} I_{k}-$ inferior volumetric annual target $\left(\mathrm{m}^{3}\right)$ to be exploited in the time period $k$ of the planning horizon; ${ }^{V} S_{k}-$ superior volumetric annual target $\left(\mathrm{m}^{3}\right)$ to be exploited in the time period $k$ of the planning horizon; ${ }^{A I_{k}}$ - inferior target area (ha) to be exploited in the time period $k$ of the planning horizon; ${ }^{A} S_{k}$ - superior target area (ha) to be exploited in the time period $k$ of the planning horizon.

Objective Function:

$$
\operatorname{Max} \operatorname{VPR}: \sum_{i=1}^{M} \sum_{j=1}^{P} r_{i j} x_{i j}
$$

Constrains

$$
\begin{aligned}
& \sum_{j=1}^{P} x_{i j}=1, \\
& \sum_{i=1}^{M} \sum_{j=1}^{P} v_{i j k} x_{i j k} \geq V I_{k}, \quad \forall_{k=\{1,2, \ldots, H P\}} \\
& \sum_{i=1}^{M} \sum_{j=1}^{P} v_{i j k} x_{i j k} \leq V S_{k}, \quad \forall_{k=\{1,2, \ldots, M} \\
& \sum_{i=1}^{M} \sum_{j=1}^{P} a_{i j k} x_{i j k} \geq A I_{k}, \quad \forall_{k=\{1,2, \ldots, H P\}} \\
& \sum_{i=1}^{M} \sum_{j=1}^{P} a_{i j k} x_{i j k} \leq A S_{k}, \quad \forall_{k=\{1,2, \ldots, H P\}} \\
& \sum_{i=1}^{M} \sum_{j=1}^{P} v_{i j k} x_{i j k}=\sum_{i=1}^{M} \sum_{j=1}^{P} v_{i j k+1} x_{i j k+1}, \forall_{k=\{1,2, \ldots, H P-1\}} \\
& \sum_{i=1}^{M} \sum_{j=1}^{P} a_{i j k} x_{i j k}=\sum_{i=1}^{M} \sum_{j=1}^{P} a_{i j k+1} x_{i j k+1}, \forall_{k=\{1,2, \ldots, H P-1\}} \\
& x_{i j} \in\{0,1\} \\
& \forall{ }_{j}, \forall_{i}
\end{aligned}
$$

Due to the imposition of a complete cut for each strip, being the partial cut excluded, the integer linear programming was used, whose decision variable took a binary form $\{0,1\}$, in which the integrity is granted by the use of only one management alternative per compartment. According to legislation, there are restrictions to exploitation of species whose cutting is forbidden, however, this aspect is not processable in the mathematical model due to lack of information.

Eight scenarios were considered in this work (Table 2), with variations in the volumetric constraints (volume control), area constraints (area control) and a combination of these two controls. The tested scenarios have the same equations with relation to the objective function, and the same binary and integrity constraints, being differentiated only by specific constraints. The software IBM ILOG CPLEX 12.2 Optimization Studio was used for data modeling and processing, considering the branch and cut algorithm. 
Table 2. Technical information for forest regulation involving mathematical models and respective tested scenarios.

Tabela 2. Informações técnicas para a regulação florestal envolvendo os modelos matemáticas e seus respectivos cenários testados.

\begin{tabular}{|c|c|c|c|c|c|}
\hline \multirow{2}{*}{ Scenario } & \multirow{2}{*}{$\begin{array}{c}\text { Equations used in the mathematical } \\
\text { model formulation }\end{array}$} & \multicolumn{2}{|c|}{$\begin{array}{l}\text { Area control } \\
\left.\text { (ha.vear }{ }^{-1}\right)\end{array}$} & \multicolumn{2}{|c|}{$\begin{array}{c}\text { Volume control } \\
\left(\mathrm{m}^{3} \text {.year }{ }^{-1}\right)\end{array}$} \\
\hline & & $\begin{array}{l}\text { Inferior } \\
\text { limit }\end{array}$ & $\begin{array}{c}\text { Superior } \\
\text { limit }\end{array}$ & $\begin{array}{l}\text { Inferior } \\
\text { limit }\end{array}$ & $\begin{array}{c}\text { Superior } \\
\text { limit }\end{array}$ \\
\hline 1 & 1,2 and 9 & \multicolumn{2}{|c|}{ Without constraints } & \multicolumn{2}{|c|}{ Without constraints } \\
\hline 2 & $1,2,5,6$ and 9 & 485 & 515 & - & - \\
\hline 3 & $1,2,3,4$ and 9 & - & - & 18,000 & 21,000 \\
\hline 4 & $1,2,3,4,5,6$ and 9 & 485 & 515 & 18,000 & 21,000 \\
\hline 5 & $1,2,3,4,5,6$ and 9 & 425 & 575 & 18,000 & 21,000 \\
\hline 6 & $1,2,8$ and 9 & \multicolumn{2}{|c|}{ Even flow } & - & - \\
\hline 7 & $1,2,7$ and 9 & - & - & \multicolumn{2}{|c|}{ Even flow } \\
\hline 8 & 1, 2 and 9 & \multicolumn{2}{|c|}{ Even flow } & \multicolumn{2}{|c|}{ Even flow } \\
\hline
\end{tabular}

\section{RESULTS AND DISCUSSION}

\section{The forestry project}

The effective management area of the project is 6,849.12 ha, divided into 83 compartments and 940 strips, with maximum strip width of $100 \mathrm{mt}$ and compartments area of approximately $100 \mathrm{ha}$. The area has an estimated total woodstock of approximately $253,213 \mathrm{~m}^{3}$, corresponding to a gross revenue of $\mathrm{R} \$ 5,880,330.74$, under the hypothesis that a complete clear cut was possible in the area.

During the division of the area in compartments it was noticed that the biggest compartment was 103.5 ha and the smallest was only 12.071 ha, and the latter had also the smallest estimated volumetric production equal to $558.5 \mathrm{~m}^{3}$. On the other hand the most productive compartment had a woodstock of $4,872.6 \mathrm{~m}^{3}$.

Analyzing the number of the generated strips, it was noticed that compartment 78 had 30 strips representing the biggest number, while compartments 33 and 59 had only 4 strips, the smallest number of strips per compartment. Variations in the area of compartments and in the number of strips are due to the characteristic shape of the studied area, such that the presence of watercourses, and consequently of permanent preservation areas (APP), affect the boundaries of the compartments, limiting the standardization options and thus the possibility to create geometrically defined shapes, as can be verified in the map of the area. Those information are important to demonstrate the level of complexity of a forestry project in terms of area and volume variations, and how difficult its regulation can be.

\section{Analysis of scenarios}

There was a variation in the processing time of the eight scenarios, as expected, where scenario (1) had the lowest processing time (1.17 seconds) due to lack of area and volume control and also because it had the lowest number of constraints, only 83. On the other hand, scenario (2) was the most time consuming (3,600.91 seconds), being formed only by the area control (Table 3$)$.

The number of decision variables was the same for all the tested scenarios, equal to 1,162 , thus including the 14 management alternatives for the 83 compartments in the area. Constraints for each scenario varied according to the tested one, with a minimum of 83 (scenario 1), without area and volume control, and a maximum of 139 (scenarios 4 and 5), considering area and volume control together.

The objective function of the model was intended to maximize the PVR for the different scenarios, although scenarios $4,6,7$ and 8 were unviable due to the difficulty to reach the expected targets since they presented constraints that were difficult to consider in the model. The other scenarios presented PVR values that varied from $\mathrm{R} \$ 4,004,561.58$ and $\mathrm{R} \$ 4,672,285.74$ respectively for scenarios 5 and 1 (Table 3).

The maximum PVR can be observed in the scenario 1, since there was no control for the area and volume, resulting in the maximum possible exploitation for the year 1, resulting in the simultaneous 
logging of the 83 compartments in the years 1 and 8 . In the other scenarios there was a small difference observed between the PVR values, because there were limitations on area, volume or both. Thus the interest rate affected the area to be exploited due to decapitalization for year zero, as expected.

Table 3. Analysis of processing results of the scenarios evaluated by ILP.

Tabela 3. Análise dos resultados do processamento dos cenários avaliados via PLI.

\begin{tabular}{lccccc}
\hline Scenario & Decision variables & constraints & Time (s) & $\begin{array}{c}\text { PVR } \\
\text { (millions } \\
\text { R\$) }\end{array}$ & $\begin{array}{c}\text { Volume } \\
\text { (thousands m }\end{array}$ \\
\hline 1 & 1,162 & 83 & 1.17 & 4.67 & 258.1 \\
2 & 1,162 & 111 & $3,600.91$ & 4.13 & 270.6 \\
3 & 1,162 & 111 & 64.07 & 4.00 & 273.9 \\
4 & 1,162 & 139 & $3,188.82$ & - & - \\
5 & 1,162 & 139 & 100.38 & 4.00 & 273.9 \\
6 & 1,162 & 96 & 360.00 & - & - \\
7 & 1,162 & 96 & $1,186.47$ & - & - \\
8 & 1,162 & 109 & $2,348.61$ & - & - \\
\hline
\end{tabular}

Forest regulation, however, has a price consisting in the difference between the PVR of the considered scenario and the maximum PVR (scenario 1), representing thus the price paid for production regulation (volume and area). Expenses to balance production for the entire area over the planning horizon varied from $\mathrm{R} \$ 540,475.07$ and $\mathrm{R} \$ 667,724.16$. Price of regulation is depending on the revenue to be received, in other words it is not a price paid to regulate the forest but it represents a lack of gains. Evaluating the total volume to be harvested in each scenario, it is observable that volume of scenario 1 is the lowest, however its PVR is the highest, showing how even with a lower volume harvested, the position in the list of the more profitable scenarios is not altered, mostly because of the annual interest rate considered in the study, that was $8 \%$.

The comparison between area to be harvested in the various possible scenarios shows that scenario 1 is harvested only in the years 1 and 8 , and $50 \%$ of its entire area is logged in these years, for a total of around 3,500 ha (Graph 1), as was expected. Harvesting of such big cerrado areas in just one year, with the alternated strips system, could demand a great number of field teams, machinery and so on, demanding a great mobilization of resources and an accurate logistic plan, that, depending on the region, could result in a technically impossible operation.

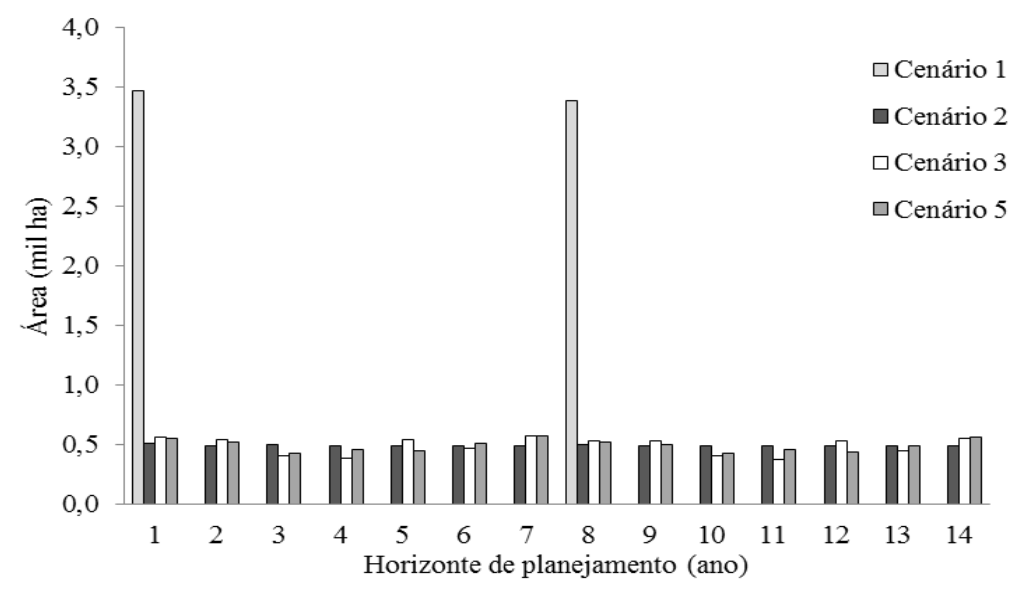

Graph 1. Areas to be harvested over the planning horizon for the scenarios that obtained optimal solution.

Gráfico 1. Áreas a serem exploradas ao longo do horizonte de planejamento para os cenários que obtiveram solução ótima. 
In years 1 and 8 the scenario 1 still have the biggest volumetric productions in a single year. However, the objective of this study was the forest regulation with the intention to obtain a regular production, as constant as possible, within an interval with inferior and superior limits of area and volume. Thus the scenario 1 is not a good option to be chosen, since it does not provide a regular production over time, the forest would not be actually regulated.

Comparing scenarios 2 and 3, the lack of constraints in area control allowed a variation of 198.0 ha (from 377.2 to 575.2 ha) in scenario 3 , and only 30 ha (from 485 to 515 ha) in scenario 2 . This shows how constraints of this nature are important.

Comparison of the volumetric exploitation between scenarios 2, 3 and 5 (Graph 2) shows that scenarios 3 and 5 were successful in reaching the target, granting balanced volumetric productions over the planning horizon. However, scenario 2, not having this type of control, allowed a volume variation of $22,461.9 \mathrm{~m}^{3}\left(7,211.5 \mathrm{~m}^{3}\right.$ and $\left.29,673.4 \mathrm{~m}^{3}\right)$, fact that was not observable in scenarios 3 and 5 , with variations of $3000 \mathrm{~m}^{3}$ (18.000 to $\left.21.000 \mathrm{~m}^{3}\right)$.

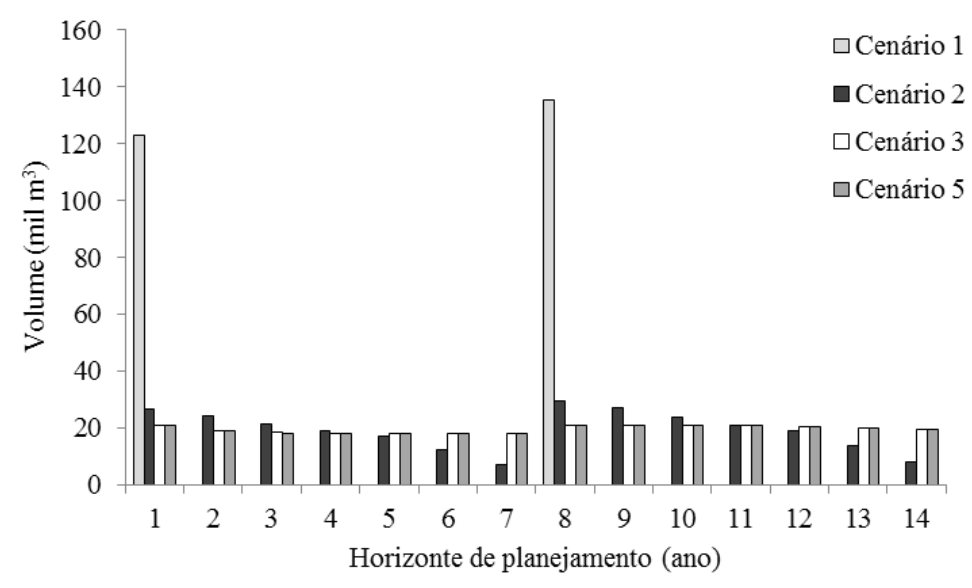

Graph 2. Volumes to be harvested over the planning horizon for the scenarios that obtained optimal solution.

Gráfico 2. Volumes a serem exploradas ao longo do horizonte de planejamento para os cenários que obtiveram solução ótima.

The analysis of scenarios altogether shows that scenario 5, which has volume and area constraints, presents the best result in terms of forest regulation compared to the others, with a decrease of $14.29 \%$ from the maximum possible PVR (scenario 1).

It is further noted that volume control is the most difficult to be obtained, when compared to area control, since area constraints could be reduced to an amplitude of 30 ha (3\% of the average that was 500 ha), while volume constraints had a minimum amplitude of $3000 \mathrm{~m}^{3}(7.59 \%$ of the average, that was $19,500 \mathrm{~m}^{3}$ ). Thus, when these intervals were tested altogether (scenario 4), there was no solution to the problem. One hypothesis to solve this problem is the division of the area to be managed in smaller compartments, increasing the number of possible combinations, however this solution would increase the operational difficulties when eventually applied.

\section{Operational scheduling of the harvesting activities for the management plan.}

Scheduling of the forest harvesting can be planned according to the optimum solution of the model, considering the best scenario (5). The number of strips and compartments to be harvested each year are different year by year (Table 4), however the area and volume control is respected. The compartments harvested in a determined year $i$ will be visited by the logging team in the time $\mathrm{i}+7$, such that $i=\{1,2, \ldots, 7\}$, alternating even and odd strips according to the managing prescription to be followed. 
Table 4. Forest harvest scheduling plan for the cerrado considering the scenario 5 analysis.

Tabela 4. Agendamento da exploração florestal para o plano de manejo do cerrado considerando a análise do cenário 5 .

\begin{tabular}{lcccc}
\hline Planning horizon & Área (ha) & Volume $\left(\mathbf{m}^{\mathbf{3}}\right)$ & Number of strips & $\mathbf{N}^{\circ}$ of compartments \\
\hline 1 & 547.43 & $20,920.03$ & 87 & 17 \\
2 & 516.67 & $19,215.38$ & 73 & 12 \\
3 & 425.66 & $18,234.57$ & 45 & 9 \\
4 & 456.26 & $18,009.92$ & 50 & 10 \\
5 & 443.96 & $18,035.01$ & 62 & 10 \\
6 & 509.78 & $18,006.94$ & 87 & 13 \\
7 & 565.98 & $18,000.83$ & 70 & 12 \\
8 & 513.87 & $20,999.01$ & 86 & 17 \\
9 & 501.84 & $20,990.97$ & 72 & 12 \\
10 & 425.22 & $20,883.72$ & 45 & 9 \\
11 & 454.13 & $20,754.24$ & 50 & 10 \\
12 & 438.97 & $20,446.35$ & 60 & 10 \\
13 & 490.68 & $20,116.61$ & 83 & 13 \\
14 & 558.67 & $19,277.87$ & 70 & 12 \\
\hline
\end{tabular}

\section{CONCLUSION}

- The use of linear integer programming models for the forest regulation of a cerrado sensu stricto area is valid, allowing the control of production within the annual volume and area limits. This way, scheduling of the logging activities becomes more effective, since planning permits the dimensioning of resources to be used. It also possible to observe that volume control is the most difficult to be obtained in the studied area, when compared to area control.

\section{REFERENCES}

ALVARENGA, L. H. V. Imagens de alta resolução e geoestatística na estratificação da fisionomia cerrado para inventários florestais. Dissertação (Mestrado), Universidade Federal de Lavras, Lavras, 2012.

BARREIRA, S.; BOTELHO, S. A.; SCOLFORO, J. R; MELLO, J. M. Efeito de diferentes intensidades de corte seletivo sobre a regeneração natural de cerrado. Cerne, Lavras, v. 6, n. 1, 2000.

Belo Horizonte. Portaria NDEG do IEF n. 191 de 16 de setembro de 2005. Dispõe sobre as normas de controle da intervenção em vegetação nativa e plantada no estado de Minas Gerais. Disponível em <http://www.siam.mg.gov.br/sla/action/Consulta.do >. Acessado em: 01/10/2012.

ChiaVenato, I. Administração - Teoria, Processo e Prática - 4ª Ed. 2006.

DAVIS, L. S.; JOHNSON, K. N. Forest management. 3 ed. New York: Mc Graw-Hill Book. Company, 1987. $790 \mathrm{p}$.

GOMIDE, L. R.; ACERBI JÚNIOR, F. W.; SCOLFORO, J. R. S.; MELO, J. M. de; OLIVEIRA, A. D. de; CARVAlHO, L. M. T. de; CALEGARIO, N.; FERRAZ FILHO, A. Sustainable Forest Management of Native Vegetation Remnants in Brazil. In: Jorge Martin Garcia; Julio Javier Diez. (Org.). Sustainable Forest Management - Case Studies. 1ed.Croácia: intech, 2012, v. 1, p. 77 - 96.

JOHNSON, K. N.; SCHEURMANN, H. L. Techniques for prescribing optimal timber harvest and investment under different - discussion and synthesis. Forest Science, USA, v. 18, n. 1, p. 1 - 31, 1977. 
COELHO JUNIOR, L. M.; REZENDE, J. L. P.; OLIVEIRA, A. D.; COIMBRA, L. A. B; SOUZA, A. N. Análise de investimento de um sistema agroflorestal sob situação de risco. Cerne, Lavras, MG: UFLA, v. 14, n. 4, p. 367 - 378, 2008.

LEITE, A. P. Avaliação silvicultural e econômica da vegetação de cerrado e eucalipto submetida a diferentes regimes de manejo na região noroeste de Minas Gerais. Dissertação (mestrado). Universidade Federal de Lavras, 1998.

LEUSCHNER, W. A. Introduction to forest resources management. New York: Jonh Willey \& Sons, 1984. $298 \mathrm{p}$.

MONTEVECHI, J. A. B. Pesquisa operacional: programação linear - Pesquisa. Operacional II. ItajubáMG: Escola Federal de Engenharia de Itajubá. 2000.

MORAIS, F. M.; PEREIRA, R. S.; REZENDEZ, A. V.; NAPPO, M. E.; PINTO, J. R. Estrutura e diversidade da vegetação arbórea e arbustiva em cerrado sensu stricto submetido a distúrbios antrópicos. Re.C.E.F., v. 18, n. 1, 2011.

OLIVEIRA, D.; SCOLFORO, J. R. S.; SILVEIRA, V. P. Análise econômica de um sistema agro-silvopastoril com eucalipto implantado em região de Cerrado. Ciência Florestal, Santa Maria, v. 10, n. 1, p. 1 - 19, 2000.

OliVEIRA, A. D.; MElO, A. A.; SCOLFORO, J. R. S.; REZENDE, J. L. P. de; MELO, J. I. F. Avaliação econômica da regeneração da vegetação de cerrado, sob diferentes regimes de manejo. Revista Árvore, v. 26, n. 6, Viçosa, 2002.

RUFINI, A. L.; SCOLFORO, J. R. S.; OLIVEIRA, A. D.; MELLO, J. M. de. Equações volumétricas para o cerrado sensu stricto em Minas Gerais. Cerne, Lavras, v. 16, n. 1, p. 1 - 11, 2010.

SCOLFORO, J. R. S.; MELlO, J. M.; OLIVEIRA, A. D. Inventário Florestal de Minas Gerais: Cerrado - florística, diversidade, similaridade, distribuição diamétrica e de altura, volumetria, tendências de crescimento e áreas aptas para manejo florestal. Lavras: Editora UFLA, 2008. 216 p.

SILVA, C. S. J. E. Análise econômica da produção de madeira de Candeia (Eremanthus erythropappus) em plantios. Tese (mestrado). Universidade Federal de Lavras. Lavras, 2011.

SILVA, M. L. da; RIBEIRO, C. A. A. S. Estabelecimento de rotação econômica para uma floresta regulada. Revista Árvore, Viçosa-MG, v. 30, n. 1, p. 1063 - 1072, 2006.

SILVA, M. L. da; SILVA, R. F. da; LEITE, H. G. Aplicação da programação dinâmica na substituição de povoamentos florestais. Revista Árvore, Viçosa-MG, v. 31, n. 6, p. 65 - 73, 2007. 